V.Yu. Rozov, D.Ye. Pelevin, K.D. Pielievina

\title{
EXTERNAL MAGNETIC FIELD OF URBAN TRANSFORMER SUBSTATIONS AND METHODS OF ITS NORMALIZATION
}

Purpose. Research of external magnetic field of urban transformer substations and the methods it reduction to the standard level in the living quarters of nearby. Methodology. Experiment based on the actual values the measuring magnetic flux density of the alternating magnetic field. Theories of electromagnetic field on quasi-static formulation is basis of external magnetic field of urban transformer substations description. Results. We have made comprehensive experimental researches the magnetic field of a $50 \mathrm{~Hz}$ through model urban transformer substations on the external environment. For calculating the external magnetic field of transformer substations the mathematical model of multi-dipole is proposed. It practical uses for induction external magnetic field of calculating created in nearby built in house transformer substations power $715 \mathrm{kVA}$ is proposed. Comparison of results calculation and experiment was conducted. Originality. We have established that magnetic flux density of the magnetic field does not exceed standard level in the living quarters of nearby $(0.5 \mu T)$ if quarters the location distances of more than $8 m$ from the transformer substation on the first time. Transformer substations in the built-in houses can create the dangerous to public health magnetic field which induction 1.5-7 $\mu \mathrm{T}$ in neighboring living quarters. It exceeds the normative level in 3-14 times. Practical value. We have proposed normalization methods of the external magnetic field built-in transformer substations. Methods are based on improving construction transformer substations. And methods of external passive and active shielding are considered. References 22, figures 9.

Key words: transformation substation, external magnetic field, living spaces, multi-dipole model, methods of normalization.

Целью работы является исследование внешнего магнитного поля городских трансформаторных подстанций (ТП) и методов его уменьшения в близлежащих жилых помещениях до нормативного уровня. Выполнены комплексные экспериментальные исследования магнитного поля частотой 50 Ги, создаваемого типовыми городскими ТП во внешней среде. Показано, что индукция магнитного поля в близлежацих жилых помещениях не превыщает нормативного уровня $(0,5$ мкТл), если помещения расположены на расстояниях более 8 м от корпуса ТП. Предложена мультидипольная математическая модель для расчета внешнего магнитного поля ТП и приведен пример ее практического использования для расчета индукиии внешнего магнитного поля, создаваемого в близлежащем жилом помещении ТП мощностью 715 кВА, встроенной в жилой дом. Приведено сравнение результатов расчета и эксперимента. Показано, что встроенные в жилые дома ТП могут создавать в соседних жсилых помещениях опасное для здоровья населения магнитное поле с индукцией 1,5-7 мкТл, что в 3-14 раз превыщает его нормативный уровень. Предложены методы нормализации внешнего магнитного поля встроенных ТП, основанные на совершенствовании конструкции ТП, а также методах внешнего пассивного и активного экранирования (компенсации). Библ. 22, рис. 9.

Ключевые слова: трансформаторная подстанция, внешнее магнитное поле, жилые помещения, мультидипольная модель, методы нормализации.

Introduction. The magnetic field $(\mathrm{MF})$ of the industrial frequency of $50 \mathrm{~Hz}$ is the most dangerous for people's health even with its weak but long-lasting effect [1]. The main sources that create such MF inside residential premises are power facilities located in residential areas - air and cable transmission lines (TL), as well as urban transformer substations (TS).

The maximum permissible level (MPL) of magnetic flux density of MF $50 \mathrm{~Hz}$ for the population created by electrical installations is regulated in [2] and is $10 \mu \mathrm{T}$ in the residential area and $0.5 \mu \mathrm{T}$ within the residential premises.

The most acute problem of the normalization of the external magnetic field (EMF) of the TS is in residential buildings with integrated TS $[2,6]$, when the distance between the TS and living quarters is reduced to several meters. Such houses (Fig. 1) are quite widespread in Ukraine and other countries. In addition, built-in TS began to be widely used in the world to supply sections of 10-20 floors in modern high-rise residential buildings [7] in order to reduce power losses. The problem of normalizing their MF also needs to be solved.

At present, the MF of the TLs have been most thoroughly studied and the methods of its reduction to a safe level for the population have been determined [3-5].
At the same time, the study of the EMF of the TS was not given due attention, although in some cases - when the TS approached the living quarters, their MF may exceed the MPL.

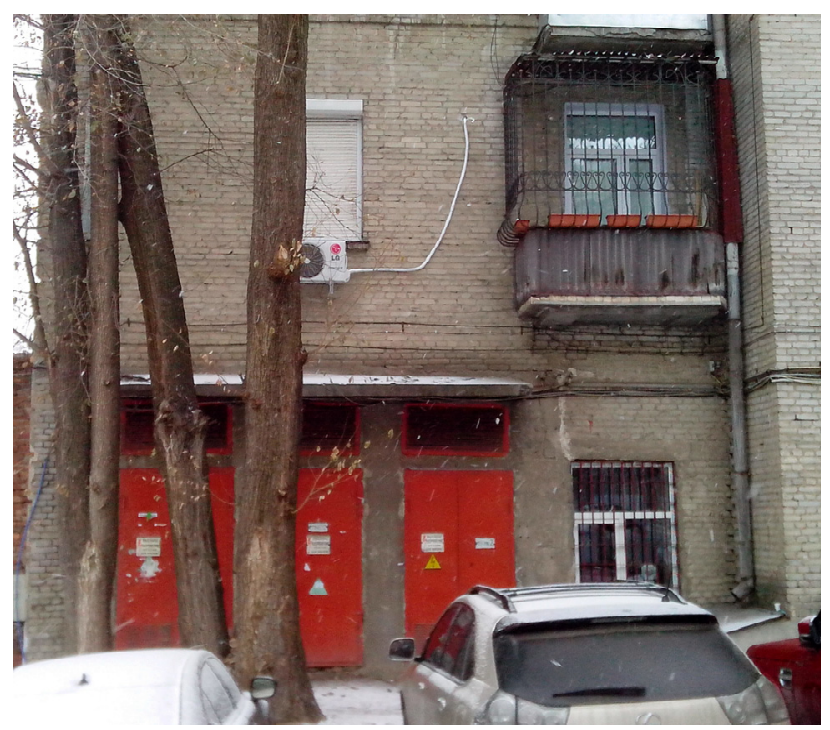

Fig. 1. A typical residential building with built-in TS (Kharkiv, Danilevsky Str., 19)

(C) V.Yu. Rozov, D.Ye. Pelevin, K.D. Pielievina 
Thus, the EMF of the TS is currently not sufficiently investigated, which makes it difficult to solve the actual and socially significant problem of the normalization of the $\mathrm{MF}$ at frequency of $50 \mathrm{~Hz}$ in the premises of apartment houses located near the TS.

The goal of the work is investigation of the EMF of urban TS and methods for reducing it to the normative level in nearby residential premises.

TS as a source of the MF. Urban TSs provide electricity for residential buildings. They perform the functions of converting three-phase high voltage of 6 (10) $\mathrm{kV}$ into voltage of $0.38 \mathrm{kV}$ and distributing electric energy of $380 \mathrm{~V}(220 \mathrm{~V})$ to end users [2, 6]. Typical urban TS (Fig. 2) have power from $100 \mathrm{kVA}$ to 1400 $\mathrm{kVA}$ and are equipped with one or two lowering threephase transformers with grounded neutral. TS contain partitioned switchgears (SG) from current conductors (buses, cables) with the necessary switching, protective and measuring equipment.

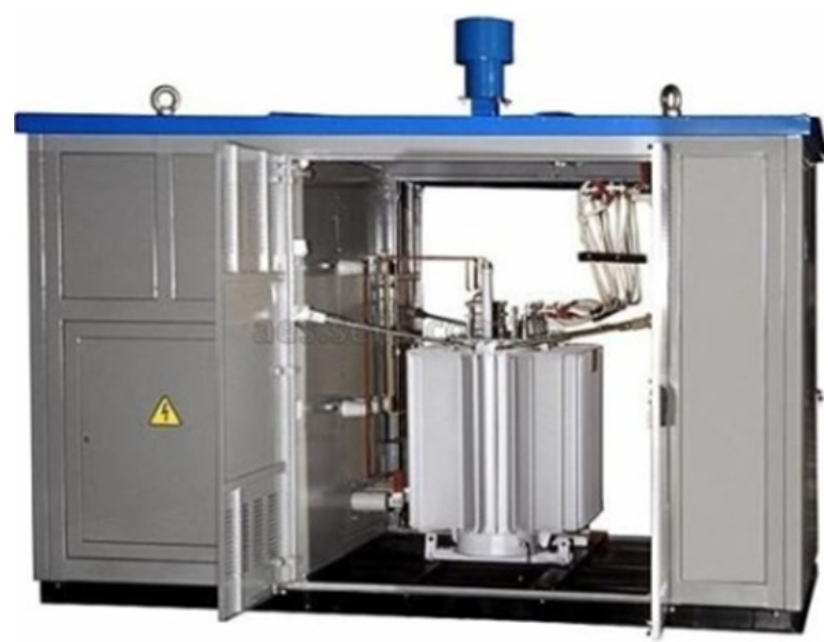

$a$

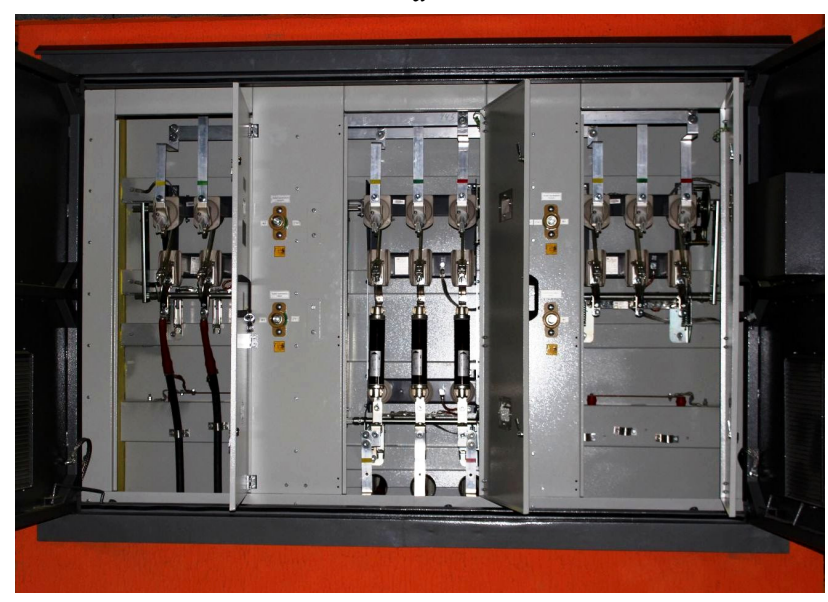

b

Fig. 2. Design of urban TS $(a)$ and its SG (b)

The main sources of the EMF of the TS are threephase current conductors of the SG, each of which, with a symmetrical load of different phases, generally forms three current circuits $[5,8,9]$, creating the MF.

Three-phase transformers of the SG have a symmetrical design theoretically excluding the creation of the EMF [8]. In practice, they create the EMF caused by technological deviations from symmetry [8, 10]. The magnetic flux density of this MF is insignificant and does not exceed $10 \%$ of the total EMF of the TS. The EMF of the transformer has a dipole character [9], rapidly decays when removed from the TS (Fig. 3) and is not taken into account in further analysis.

The other elements of the SG, including switchgear, protective and measuring equipment of the TS, as well as input and output twisted three-phase cables, also practically do not affect the EMF of the TS [9].

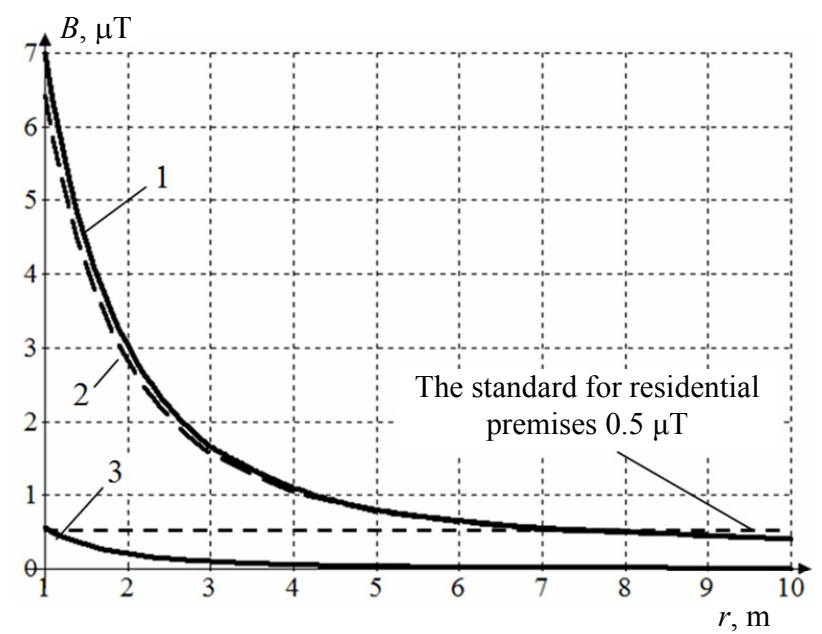

Fig. 3. Characteristic decrease in magnetic flux density of the MF of the TS of type K-42-630 at removal from distance $r$ from its housing ( 1 - total MF of the TS, $2-$ MF of current conductors, 3 - MF of the transformer)

Thus, the EMF of the TS is determined by the MF of three-phase current conductors of the TS which can be represented in accordance with Fig. 4.

Experimental investigations of the EMF of the TS. Experimental investigations of the EMF of the TS have been performed for 42 TS of city of Kharkiv with nominal power $\left(S_{\text {nom }}\right)$ from 100 to $1260 \mathrm{kVA} .36 \mathrm{TS}$ located in separate buildings (inside microdistricts) and 6 TS built into residential buildings were investigated.

The research is based on direct measurements of the effective value of the magnetic flux density of alternating $\mathrm{MF}$ in a limited number of points using a Magnetoscop 1.069 magnetometer by Foerster Company (magnetic flux density measurement range $0-600 \mu \mathrm{T}$, relative error $2.5 \%$ ) and EMF-828 (magnetic flux density measurement range $0-2000 \mu \mathrm{T}$, relative error $4 \%$ ).

The magnetic flux density of the MF at the $i$-th point of the measurement was determined from the measurements of the magnetic flux density of the MF in the three orthogonal positions of the magnetometer sensor using formula

$$
B_{i}=\sqrt{B_{x i}^{2}+B_{y i}^{2}+B_{z i}^{2}},
$$

where $B_{x i}, B_{y i}, B_{z i}$ are the measured effective values of the spatial components of the magnetic flux density of the MF at the $i$-th measurement point along the axes of the magnetometer sensors $X, Y, Z$.

The beginning of the coordinate grid was combined with the surface of the TS housing. MF measurements were carried out at the distance from the TS in the 
horizontal (vertical) direction corresponding to the maximum values of the MF with the fixation of the actual currents in the current conductors of the TS. The resulting magnetic flux density value of the MF of the TS was reduced to the rated power of the TS.

In the residential zone, the measurement points were located on lines perpendicular to the walls of the building, in increments of $1 \mathrm{~m}$ height of $1 \mathrm{~m}$. When measuring MF in nearby residential premises, the measurement points were located in the nodes of a spatial grid parallel to the walls of the premises. The basic grid of measurements had a step of $0.5 \mathrm{~m}$ and was located in a horizontal plane, at an altitude of $0.5 \mathrm{~m}$ from the floor of the room.

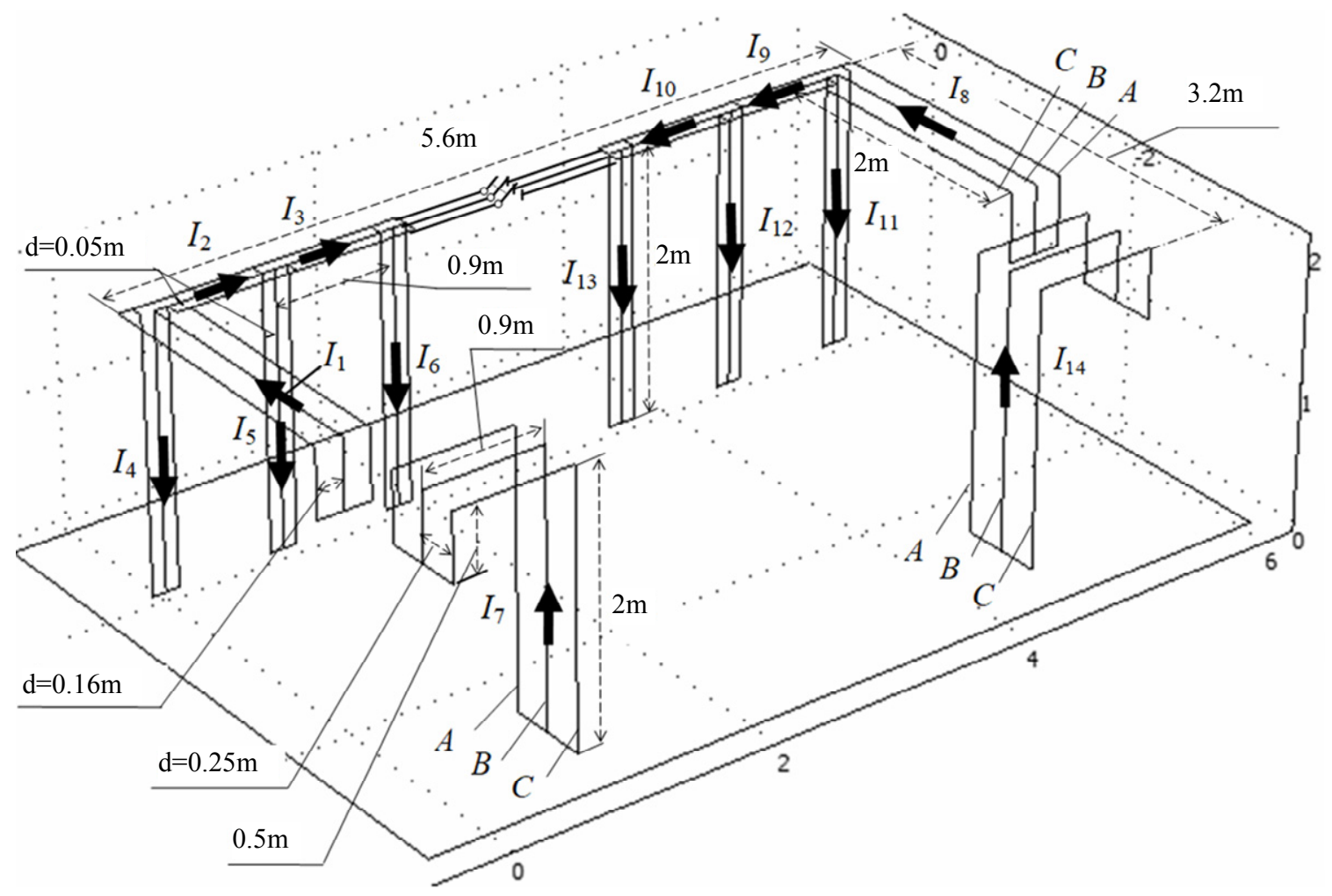

Fig. 4. Configuration of the current conductors of the considered two-transformer TS of power of $715 \mathrm{\kappa VA}$

The generalized results of measurements of the magnetic flux density of the MF of the TS of different power are shown in Fig. 5 where the value of the magnetic flux density near the external wall of the room of the TS corresponds to $r=2 \mathrm{~m}$, the distance between which and the housing of freestanding TS is $2 \mathrm{~m}$.

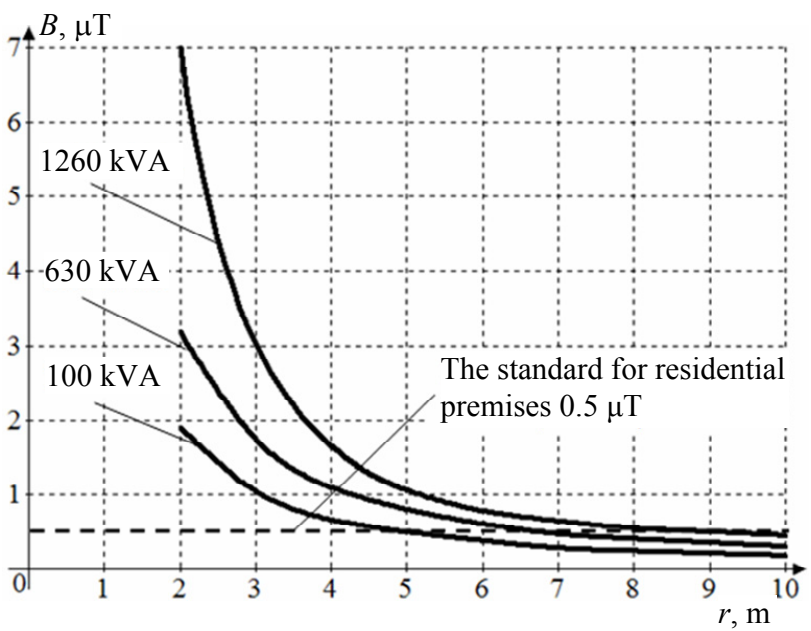

Fig. 5. Experimental values of the magnetic flux density of the EMF of stand-alone TS of various power reduced to their nominal load when removing the measuring point from their housing ( $r$ is the distance of the TS housing to the point of observation)
An analysis of the results of experimental investigations shows the following. The magnetic flux density of the EMF of the TS falls to the MPL $(0.5 \mu \mathrm{T})$ at the distance of $8 \mathrm{~m}$ from the TS of maximum power $(1260 \mathrm{kVA})$. At the minimum power of the TS (100 kVA), its EMF drops to the MPL at the distance of $5 \mathrm{~m}$.

Since all stand-alone TS are located more than $15 \mathrm{~m}$ from residential buildings, they do not represent the dangers for its residents.

The maximum magnetic flux density of the EMF of the TS under consideration (Fig. 5) occurs near the outer walls of their premises and is $7 \mu \mathrm{T}$ which does not exceed the MPL for the residential development area $(10 \mu \mathrm{T})$ in accordance with [2].

Therefore, urban TS do not pose a public health hazard when they are located at the distance of more than $8 \mathrm{~m}$ from residential buildings. However, this condition is violated for in-built TS when the distance between the TS housing and living quarters is reduced to several meters.

Thus, Fig. 6 shows the magnetic flux density distribution of the MF built from the results of measurements in a residential building located on the first floor of the house (Fig. 1) above the built-in twotransformer TS with power of $715 \mathrm{kVA}$. The distance 
from the TShousing to the floor of a residential building on the first floor is $1.85 \mathrm{~m}$. The actual load of the TS during the measurements was $45 \%$ of the nominal $\left(0.45 \cdot S_{\text {nom }}\right)$.

The results of the measurements are shown in Fig. 6. Their analysis shows that the maximum level of the magnetic flux density of the MF in a residential building above the built-in TS even at the reduced load of the TS $\left(0.45 \cdot S_{\text {nom }}\right)$ is $1.6 \mu \mathrm{T}$ which is more than 3 times than the MPL. With larger installed power of the TS operating at the rated load mode, the magnetic flux density value of the MF in accordance with Fig. 5 can reach $7 \mu \mathrm{T}$.

Thus, the built-in TS can create in the adjacent residential premises the MF with magnetic flux density in 3-14 times exceeding the MPL which poses a danger to public health and requires taking measures to normalize their EMF.

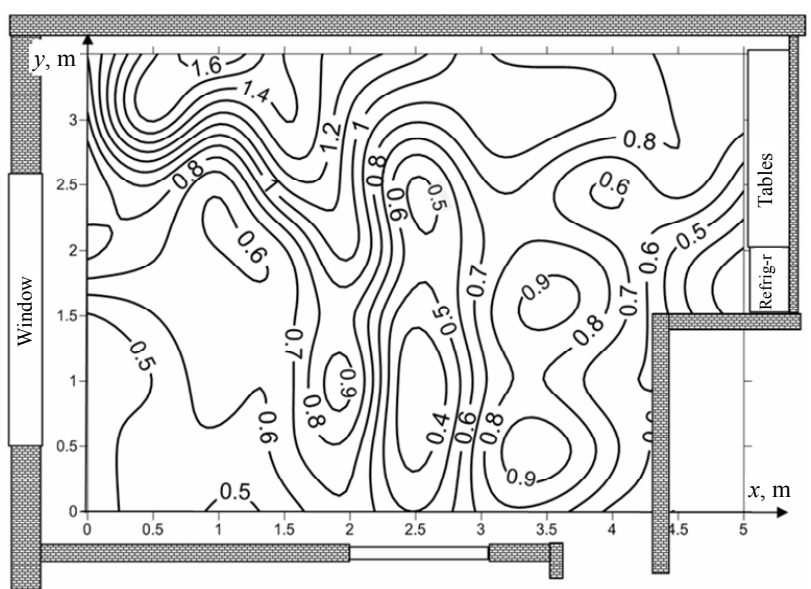

Fig. 6. Experimental values of the magnetic flux density distribution of the MF $(\mu \mathrm{T})$ at an altitude of $0.5 \mathrm{~m}$ from the floor of the living space located above the built-in TS of power of $S_{\text {nom }}=715 \mathrm{kVA}$ at the actual load $0.45 \cdot S_{\text {nom }}$

Modeling of the EMF of the TS. The analysis shows that the EMF of the TS is normalized in the outer region of space - at points remote by the distance $R_{o}$ from the TS housing. This distance is at least $2 \mathrm{~m}$ and considerably exceeds the distance $d$ between the axes of the phase conductors of the TS $(0.05-0.5 \mathrm{~m})$ [6] that creates the conditions for the application of the multidipole mathematical model in the calculation of the EMF of the TS $[8,11,12]$. This model, with a large number of current conductors with a complex configuration, which is characteristic for TS, allows us to simplify the calculation of the EMP of the TS with the limited methodological error (less than $10 \%$ ) in comparison with the Biot-Savart method and numerical methods [3, 8]. In addition, the multi-dipole model has a clear physical interpretation, which makes it easier to synthesize the means of reducing the MF based on it [3].

In order to build a multi-dipole model of the EMF of the TS, the approach realized in [3] can be used when each linear circuit with current $I$ of the TS (Fig. 4) with the length $L$ and the width $d$ is arbitrarily divided into $N$ elementary microcontours with areas $S_{i}=a_{i} \cdot d$ characterized by dipole magnetic moments $\dot{\vec{m}}_{i}$ (Fig. 7). In this case, it is necessary to satisfy the following conditions $[3,8]$ :

$$
R_{0}>2 d ; R_{0}>2 a ; a=\frac{L}{N}<0,5 R_{0} .
$$

In this case, the magnetic flux density of the MF $\dot{\vec{H}}_{k}(P)$ produced by a single rectilinear single-phase current loop (Fig. 7) at the observation point $P$ can be determined by the expressions $[3,8]$

$$
\begin{gathered}
\dot{\vec{H}}_{k}(P)=-\sum_{i=1}^{N} \nabla\left[\frac{\left(\dot{\vec{m}}_{i}, \vec{R}_{i}\right)}{4 \pi R_{i}^{3}}\right] ; \\
\dot{\vec{m}}_{i}=\dot{I} \cdot \vec{S}_{i}=\dot{I} \cdot e^{-j \varphi} \cdot a_{i} \cdot d \cdot \vec{n},
\end{gathered}
$$

where $N$ is the number of microcontours in a rectangular contour of the TS; $\vec{S}_{i}$ is the vector of the square of the $i$-th microcontour; $\vec{n}_{i}$ is the unit vector normal to $S_{i} ; \vec{R}_{i}$ is the radius-vector from the geometrical center of the $i$-th microcontour to the observation point $P ; \varphi$ is the phase of the current $\dot{I}$.

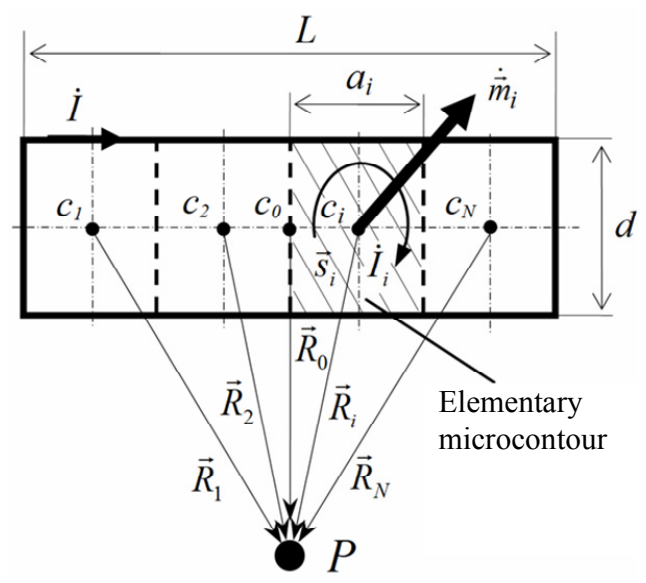

Fig. 7. Multidipole representation of the elementary contour with alternating current $\dot{I}$ as a source of the MF

Then the magnetic flux density $\dot{\vec{B}}_{T S}$ of the EMF of the TS (Fig. 4), containing $K$ three-phase rectilinear TS contours, can be defined as

$$
\dot{\vec{B}}_{T S}(P)=-\sum_{l=1}^{K} \sum_{\alpha=1}^{3} \sum_{i=1}^{N} \nabla\left[\frac{\mu_{0}\left(\dot{\vec{m}}_{l \alpha i}, \vec{R}_{l \alpha i}\right)}{4 \pi R_{l \alpha i}^{3}}\right],
$$

where $\alpha$ is the TS current conductor phase number $(\alpha=1 \ldots, 3)$; $l$ is the TS contour number $(l=1, \ldots, K)$; $\mu_{0}$ is the magnetic constant.

We use the proposed multi-dipole model (5) to calculate the magnetic flux density of the EMP of the built-in TS. The calculation will be carried out for a real urban 2-transformer TS with power of $715 \mathrm{kVA}$ built into the residential house (Fig. 1). In the calculation, we assume that the currents in the phases of all the TS circuits are sinusoidal, shifted by 120 el. degrees and form a symmetrical system. Current conductors of the TS are current threads. The external environment does not 
contain sources of the MF. The effect on the EMP of the metal parts of the TS housing and the walls of the apartment house in accordance with $[9,13]$ is neglected.

The calculation scheme of the TS corresponds to Fig. 4 and contains 18 rectilinear three-phase current contours $(K=18)$ with shown in Fig. 4 dimensions and actual currents, determined experimentally under TS load $0.45 \cdot S_{\text {nom }}: I_{1}=312 \mathrm{~A} ; I_{2}=208 \mathrm{~A} ; I_{3}=108 \mathrm{~A} ; I_{4}=104 \mathrm{~A}$; $I_{5}=100 \mathrm{~A} ; I_{6}=108 \mathrm{~A} ; I_{7}=21 \mathrm{~A} ; I_{8}=174 \mathrm{~A} ; I_{9}=114 \mathrm{~A}$; $I_{10}=62 \mathrm{~A} ; I_{11}=60 \mathrm{~A} ; I_{12}=52 \mathrm{~A} ; I_{13}=62 \mathrm{~A} ; I_{14}=12 \mathrm{~A}$.

The results of calculating the flux density of the MF in a horizontal plane located at an altitude of $2.35 \mathrm{~m}$ above the TS were performed in accordance with (5) and are shown in Fig. 8.

Comparison of the calculation results (Fig. 8) with the results of the experiment (Fig. 6) shows that the maximum calculated magnetic flux density value of MF $(1.7 \mu \mathrm{T})$ with an error of less than $10 \%$ coincides with the experimental results $(1.6 \mu \mathrm{T})$. This confirms the correctness of the proposed methodology for calculating the magnetic flux density of the EMF of the TS and the assumptions made above.

Methods of normalization of the EMF of the TS. As follows from the above analysis, the normalization of the EMF is required for TS built in residential houses, when the distance between the TS housing and the residential space is less than $8 \mathrm{~m}$. The main methods of normalizing the EMF of the TS are shown in Fig. 9.

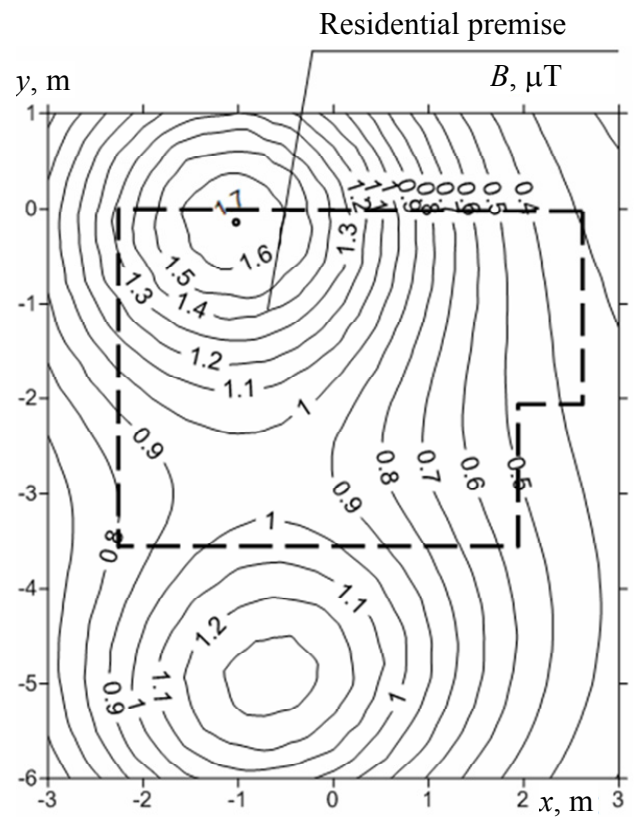

Fig. 8. Calculated values of the magnetic flux density distribution of the MF $(\mu \mathrm{T})$ at an altitude of $0.5 \mathrm{~m}$ from the floor of the living space (Fig. 1) located above the built-in TS of power of $S_{\text {nom }}=715 \mathrm{kVA}$ at the actual load $0.45 \cdot S_{\text {nom }}$

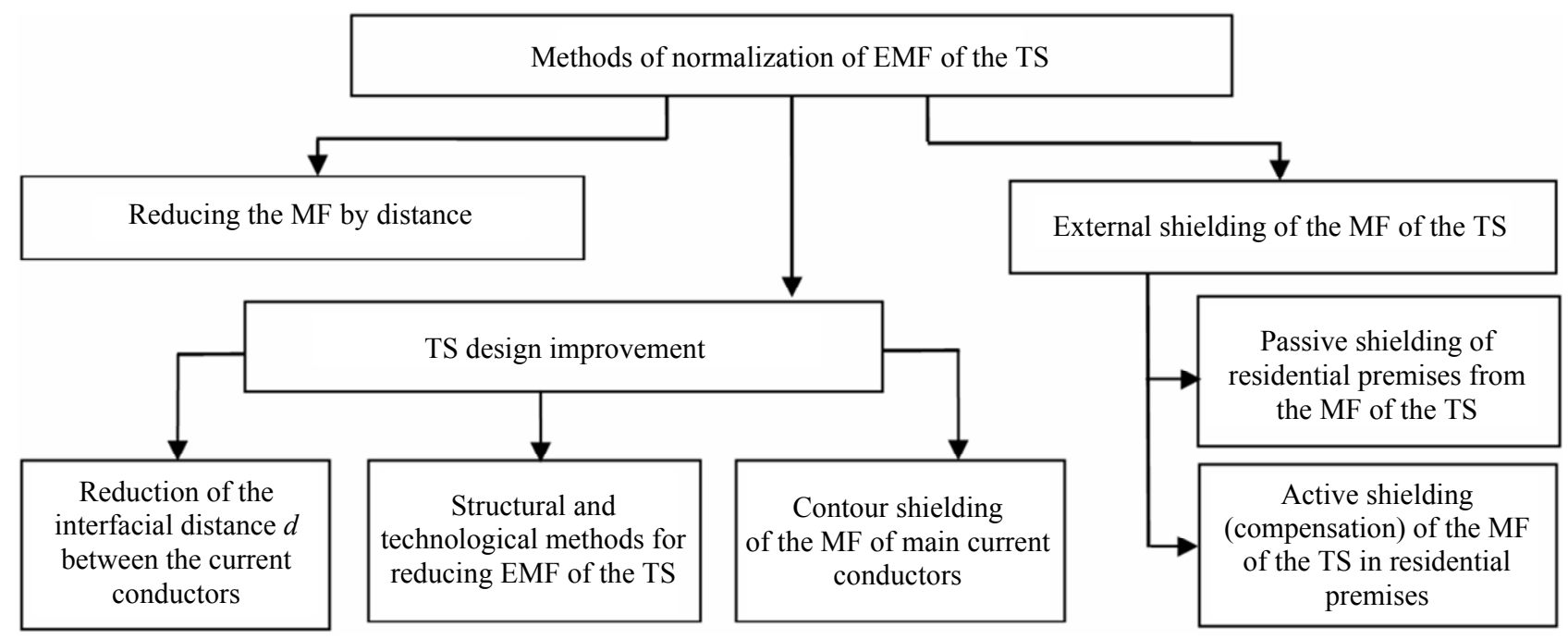

Fig. 9. Classification of methods of normalization of EMF created by the TS in nearby residential premises

The EMF of the TS falls off intensely as a function of the distance (Fig. 5) which allows to significantly reduce the MF when removing the TS from residential premises. However, the implementation of this method is possible only in the presence of free space which limits its use.

A significant decrease in the EMF of the TS is possible due to its special design of the TS. Thus, the constructive and technological methods proposed in [8, 9] (symmetrization, transposition, splitting of current conductors, local active and passive shielding of the MF) allow to reduce the EMF of the TS by an order of magnitude or more. A promising method of reducing the EMF of the TS is the contour shielding of its current leads in accordance with $[5,9]$. However, the change in the design of existing TS is technically difficult and has legal limitations, and the industrial release of TS in a special design requires significant investment.

Therefore, methods of external shielding of the MF of the TS are more preferable for practical implementation. Passive shielding is carried out with the help of electrically conductive (ferromagnetic) materials placed on walls and ceilings located near the TS of residential premises $[14,15]$. This method is universal but 
at a low frequency of $50 \mathrm{~Hz}$ its implementation requires substantial material means.

Of great interest from the point of view of the cost of realization for high efficiency are the methods of active shielding of the MF [4, 8, 9, 16-22]. However, they require their development in relation to the MF which is the subject of further research.

\section{Conclusions.}

1. Complex experimental investigations of the distribution of the flux density of the external magnetic field with frequency of $50 \mathrm{~Hz}$, created by 42 typical urban transformer substations (TS) with installed power from $100 \mathrm{kVA}$ to $1260 \mathrm{kVA}$ are performed for the first time. It is shown that the flux density of the magnetic field in nearby residential premises does not exceed the regulatory level $(0.5 \mu \mathrm{T})$, provided that the TS is removed from residential premises over the distance of more than $8 \mathrm{~m}$.

2. A multi-dipole mathematical model for calculating the external magnetic field of the TS is proposed and experimentally justified making it possible to simplify the calculation with a limited error $(10 \%)$ and having a clear physical interpretation. The model is built on the basis of dipole sources of the magnetic field, characterized by the magnetic moments of independent elementary microcontours $d \times a_{i}$ into which all the linear sections of three-phase current conductors of the TS with interphase distance $d$ are arbitrarily divided. The magnetic field at the observation point distant by more than $2 d\left(2 a_{i}\right)$ is defined as the superposition of the magnetic field created by the magnetic moments of the elementary microcontours of all the linear sections of the TS current conductors.

3. It is theoretically substantiated and experimentally confirmed that the greatest danger to public health is TP built into homes that can create in a neighboring residential area a magnetic field with the flux density of 1.5-7 $\mu \mathrm{T}$, which is $3-14$ times higher than the normative level.

4. The methods of normalizing the external magnetic field of the TS in residential premises are considered based on the improvement of the TS design, the use of external shielding (compensation) of the TS magnetic field, and the prospects for the development of methods for external active shielding of the magnetic field are substantiated.

\section{REFERENCES}

1. Serdiuk A.M., Dumanskiy V.Yu., Bitkin S.V., Didyk N.V., Dumanskiy Yu.D. Hygienical ground of requirements to placing and exploitation of cable busses of electricity transmission and their equipment in the conditions of modern municipal building. Hygiene of populated places, 2015, no.66, pp. 20-29. (Ukr).

2. Pravyla ulashtuvannja elektroustanovok 5-te vyd., pererobl. j dopovn. (stanom na 22.08.2014) [Electrical Installation Regulations. 5 edition, Revised and enlarged]. Kharkiv, Fort Publ., 2014. 800 p. (Ukr).

3. Rozov V.Yu., Reutskyi S.Yu., Pelevin D.Ye., Pyliugina $\mathrm{O} . \mathrm{Yu}$. The magnetic field of power transmission lines and the methods of its mitigation to a safe level. Tekhnichna elektrodynamika, 2013, no.2, pp. 3-9. (Rus).

4. Kuznetsov B.I., Nikitina T.B., Voloshko A.V., Bovdyj I.V., Vinichenko E.V., Kobilyanskiy B.B.. Synthesis of an active shielding system of the magnetic field of power lines based on multiobjective optimization. Electrical engineering \& electromechanics, 2016, no.6, pp. 26-30. (Rus). doi: 10.20998/2074-272X.2016.6.05.

5. Rozov V.Yu., Dobrodeyev P.N., Kvytsynskyi A.A. Doublecircuit passive shielding of the magnetic field of high-voltage cable lines in junction zones. Tekhnichna Elektrodynamika, 2017, no.1, pp. 23-28. (Rus).

6. Opoleva G.N. Skhemy $i$ podstantsii elektrosnabzheniia. Spravochnik [Schemes and substations of power supply. Directory]. Moscow, Forum-Infra Publ., 2006. 480 p. (Rus).

7. Alotto P., Guarnieri M., Moro F., Turri R. Mitigation of residential magnetic fields generated by $\mathrm{MV} / \mathrm{LV}$ substations. Universities Power Engineering Conference, 42nd International. 2007, pp. 832-836. doi: 10.1109/UPEC.2007.4469057.

8. Rozov V.Yu. Vneshnie magnitnye polia silovogo elektrooborudovaniia $i$ metody ikh umen'sheniia [External magnetic fields of power electrical equipment and methods for reducing them]. Kiev, The Institute of Electrodynamics Publ., 1995, no.772. 42 p. (Rus).

9. Rozov V. Yu., Erisov A.V., Lupikov V.S. Osobennosti snizheniia vneshnikh magnitnykh polei raspredelitel'nykh ustroistv $i$ poluprovodnikovykh preobrazovatelei [Features of reducing external magnetic fields of switchgears and semiconductor converters]. Kiev, The Institute of Electrodynamics Publ., 1996, no.791. 46 p. (Rus).

10. Zautner F.L., Pilyugina O.Yu., Rozov V.Yu. Probabilistic method for predicting electromagnetic interference of electrical equipment in the low-frequency range. Tekhnichna Elektrodynamika, 1994, no.1, pp. 3-6. (Rus).

11. Rozov V.Yu. Construction of systems for automatic compensation of external magnetic fields of mobile objects containing ferromagnetic masses. Tekhnichna Elektrodynamika. Thematic issue "Problems of modern electrical engineering», 2002, no.2, pp. 9-14. (Rus).

12. Rozov V.Yu., Getman A.V., Petrov S.V., Ericov A.V., Melanchenko A.H., Horoshilov V.S, Shmidt I.R. Magnetism of spacecraft. Tekhnichna Elektrodynamika. Thematic issue «Problems of modern electrical engineering», 2010, no.2, pp. 144-147. (Rus).

13. Rozov V.Yu., Grinchenko V.S., Pelevin D.Ye., Chunikhin K.V. Simulation of electromagnetic field in residential buildings located near overhead lines. Tekhnichna Elektrodynamika, 2016, no.3, pp.6-9. (Rus).

14. Szabó J., Jánossy G., Thuróczy G. Survey of residential 50 $\mathrm{Hz}$ EMF exposure from transformer stations. Bioelectromagnetics, 2007, vol.28, no.6, pp. 48-52. doi: 10.1002/bem.20264.

15. Burnett J., Du Yaping P. Mitigation of extremely low frequency magnetic fields from electrical installations in highrise buildings. Building and Environment, 2002, vol.37, no.8-9, pp. 769-775. doi:10.1016/S0360-1323(02)00043-4.

16. Shidlovskij A.K., Rozov V.Yu. Automatic compensation systems for external magnetic fields of energy-saturated objects. Tekhnichna Elektrodynamika, 1996, no.1, pp.3-9. (Rus).

17. Rozov V.Yu., Assuirov D.A., Reuckij S.Ju. Closed systems for compensation of the magnetic field of technical objects with different methods of feedback formation. Tekhnichna Elektrodynamika. Thematic issue «Problems of modern electrical engineering», 2008, no.4, pp. 97-100. (Rus). 
18. Rozov V.Yu., Assuirov D.A. The method of active shielding of the external magnetic field of technical objects. Tekhnichna Elektrodynamika. Thematic issue "Problems of modern electrical engineering», 2006, no.3, pp. 13-16. (Rus).

19. Voloshko A.V. Synthesis of active shielding systems of power transmission lines magnetic field. Visnyk Nac. Akad. Nauk Ukr., 2017, no.7, pp. 64-73. (Ukr). doi: 10.15407/ visn2017.07.064.

20. Cruz P., Riquelme J.M., de la Villa A., Martínez J.L. Gabased passive loop optimization for magnetic field mitigation of transmission lines: neural network applications in electrical engineering. Neurocomputing, 2007, vol.70, no.16-18, pp. 26792686. doi:10.1016/j.neucom.2006.05.016.

21. del-Pino-López J.C., Giaccone L., Canova A., Cruz-Romero P. Design of active loops for magnetic field mitigation in MV/LV substation surroundings. Electric Power Systems Research, 2015, vol.119, pp. 337-344. doi: 10.1016/j.epsr. 2014.10.019.

How to cite this article:

Rozov V.Yu., Pelevin D.Ye., Pielievina K.D. External magnetic field of urban transformer substations and methods of its normalization. Electrical engineering \& electromechanics, 2017, no.5, pp. 60-66. doi: 10.20998/2074272X.2017.5.10.
22. Garzia F., Geri A. Active shielding design of indoor MV/LV substations using genetic algorithms optimization. IEEE Symposium on Electromagnetic Compatibility, 2003, vol.1, pp.197-202.

Received 12.08.2017

V.Yu. Rozov ${ }^{1}$, Doctor of Technical Science, Corresponding member of NAS of Ukraine,

D.Ye. Pelevin ${ }^{1}$, Candidate of Technical Science,

K.D. Pielievina ${ }^{1}$, Postgraduate Student,

${ }^{1}$ State Institution «Institute of Technical Problems of Magnetism of the NAS of Ukraine»,

19, Industrialna Str., Kharkiv, 61106, Ukraine, phone: +380 572992162 ,

e-mail: pelevindmitro@ukr.net 